\title{
ENGLISH EDUCATION DEPARTMENT STUDENTS' DIFFICULTIES IN TRANSLATING ENGLISH NEWS REPORT
}

\author{
Nurlaila ${ }^{1}$ \\ 1Faculty of Tarbiyah and Teacher Training, UIN Antasari Banjarmasin, Indonesia \\ (hidayahnortbiuin@gmail.com) \\ Andi Irlina ${ }^{2}$ \\ ${ }^{2}$ Faculty of Tarbiyah and Teacher Training, UIN Antasari Banjarmasin, Indonesia \\ (andi.irlina23@gmail.com)
}

\begin{abstract}
Different language systems between English and Indonesian cause difficulties in communication, both written and oral. This case can be solved with translation. This research aims to find about types of translation difficulties in translating English news reports encountered by the fourth semester of English Education Department students of Tarbiyah and Teacher Training Faculty at UIN Antasari Banjarmasin. This research is a qualitative descriptive research by analyzing the text of the news report entitled "London is the Best Destination in the World in the 2019 Trip Advisors Travellers' Choice Awards," published on 29 March 2019 at 00.48:00 a.m translated into Bahasa Indonesia by involving 50 of the students. The number of the students are the participants taken by using purposive sampling. The writers collect the written documents due to translating the text of the English News Report by the students, analyze the words, phrases, and sentences to find the students' difficulties based on Hartono's theory. There are four difficulties the writers found in this study. The difficulties are lexical, grammatical, stylistic, and cultural difficulties.
\end{abstract}

Keywords: Translation; English News Report

First Received:

(September 13, 2021)
Final Proof Received:

(September 30, 2021)

\section{INTRODUCTION}

Living in the era of information technology, it goes without saying that nowadays, people can perceive what is happening worldwide. Social media spread all the globe, offering varieties of information. English as an international language is used dominantly in English news reports in most parts of the World. Many people in Indonesia have difficulties in understanding English news reports. The difficulties are due to the role of English as a foreign language in Indonesia. Therefore, translation becomes a medium function to understand the language.

Many Indonesian students usually do translation by using google translation or another online site to understand the meaning, which is the translation result can be unreadable and uneasy about comprehending a whole meaning. This is due to the failure to understand the basic knowledge of translation principles that a translation does not simply transfer the words and sentences literally from the source language into the target 
language. However, the translation must be able to transfer the meaning from the source language text into the target language ones, Bell (as cited by Ordudari, 2007).

In addition, different language systems between English and Indonesian cause difficulties in communication, both written and oral. This case can be solved with translation. Different cultural backgrounds may also present their own unique challenges. Therefore, before translating a text, a translator should do some processes such as studying the language system and cultural context of the source language text, analyzing the text, and reconstructing the text that contains equivalence messages to the target language text (Larson, 1998).

Viewing the definition and the process of translation above, the translator and the student should analyze the source text by studying the lexicon, grammatical structure, communication situation, and cultural context of the source text to find the conveyed meaning/message in the text and then convey the same message in the target language in the lexicon and structure of the target language, while most of the students did not recognize those important aspects for doing translation including in translating English news report.

The researchers took several of the relevant theses as previous studies. The first is Mu'minah (2017). Her study aims to know what kind of errors students make and the causes of making errors made by the eleventh grade of SMA Muhammadiyah Purworejo in Translating English to Indonesian on the recount text. In this study, the researcher uses the descriptive qualitative method to analyze the data. The causes of error that make students produce errors in this research reflect the general characteristics, such as faulty generalization, incomplete application of rules, and failure to learn conditions under which rules apply.

The second is (Dony, 2017). His study is aimed to find out the correlation between (1) translation ability and writing ability; (2) reading habit and writing ability; (3) translation ability and reading habit toward writing ability. The conclusion of his research shows a significant positive correlation between translation ability and reading habit toward writing ability among the twelfth-grade students of MAN 2. It means translation ability, and reading habit is a good predictor for the student's writing ability.

The third is (Yazida, 2017). He discussed the kinds of errors the students made and the causes of the students' errors in translating descriptive text. To conduct his research, he used descriptive-analytical research. In his research, he used essay tests as an instrument. The essay is about Indonesian text which is translated to English. Then the writer analyzed the students' test by classifying the errors based on Azar's classification; pronoun, sentence pattern, tenses, preposition, spelling, and punctuation. This research stated that the researcher got the result of grammar errors made by ten graders at MAN 3 Amuntai in translating descriptive text. Mother Tongue Interference caused these errors. It was classified errors in Sentence Pattern as the errors in Omission. The translation was 
classified in Tense as the errors in Omission. Overgeneralization was classified errors in pronouns as the errors in Selection. Overgeneralization was classified errors in prepositions as the errors in Omission; Carelessness was classified errors in spelling and punctuation as the errors in Selection.

The differences between the researcher's study and previous research are the object of the research, while the researcher chooses students' difficulties in translating. The researcher uses descriptive qualitative to conduct the research and apply Hartono and Nababan's type of translation difficulties as the theory to classify the difficulties found in students' translation. The writer also uses an essay test as an instrument, while an interview is used to get supporting data.

In this case, translating news reports presents its own unique challenges. Much of it has to do with the fact that news reports are made up of different sections and types of articles, each with their own style and language. In translating news reports, a translator must consider several things, such as style, terminology, and cultural context. That is why translating news reports becomes more complicated than other types of texts because the translator not only transfers the meaning of the text but also considers other aspects.

\section{LITERATURE REVIEW}

The translation process is not an easy activity because the language across the country has different concepts like English and Indonesian. Both of the languages have different linguistic and cultural contexts. The differences in the language of the two countries make the process of translation difficult. Therefore, before translating, a translator should know about the meaning of the text and understand the message of the original text so that she/he can find the most equivalent meaning of the source language text into the target language text.

There are three procedures of the translation process suggested by Nida and Taber. The procedures are: analysis, transfer, and restructure. So, before beginning to translate, firstly, a translator must understand the message of the source language text by analyzing the words, phrases, and syntactical structure of the text. Secondly, the translator transfers the messages to find a similar meaning to the original text. Finally, the translator restructuring the text which has accepted sentence pattern that the target readers can understand the text well (Nida \& Taber, 1974)

According to Hariyanto \& Suryawinata (2003), there are six principles of translation that can help us to translate from source language to target language:

1. The translation should use the text of the source language.

2. We felt like it was reading what was translated while reading the translation.

3. The translation must be based on the style of the source language.

4. Author's contemporary. 
5. The translation may not add or subtract things from the source language text to the target language text.

6. Literary types of that text should be maintained.

When we translate a certain text into the target language, it must use a literal translation as used in the source language. For example, poetry must translate to poetry.

According to Rachmadie (as cited in Hariyanto \& Suryawinata, 2003), hardly any text can be translated with the same resemblance to the source language. It's difficult to translate a text that is similar to the original text. We should translate word by word for the detailed translation. But, it makes the meaning is not appropriate and elusive.

These are also six principles of translation for readers:

1. The idea of the source language is similar to the target language.

2. The source text is similar to the target text in flexibility.

3. The style may differ, depends on the language.

4. The time contemporary.

5. Flexible.

6. The genre may differ from source text to the target text.

The principles of translation above must present an idea of the original text and make it flexible, easy to read, and understand. The translation should not follow the source language and can add or subtract the original text elements. But, especially for the last principles above, some people disagree because they argue that poetry should translate to be a poetry. There is no specific rule to translate. The translator can use appropriate language to describe the original text's meaning (Hariyanto \& Suryawinata (2003).

Technique in translation is very important because it can help translators produce the structure of the words, phrases, clauses, and sentences. That will not only produce accurate translations, but it is also acceptable and easy to read by the target language readers. It can also represent other cultures. In this case, Harvey (2003) puts forward the following four major techniques for translating culture Bound Terms (CBTs):

1. The cultural function of the source language is equivalence to the source language

2. Linguistic equivalence

3. Transcription or borrowing

4. Use clear and simple language.

The different language systems of English and Indonesian may cause some difficulties encountered by translators. There are some difficulties the translators may have. Hartono (2009) classified it as follows:

\section{Lexical Difficulties}

The lexical difficulty usually appears when the translator cannot understand, misunderstand, or barely does not know the meaning of a word or an expression. This 
case may relate to the background knowledge about vocabulary mastery and familiarity with the context. Davies (2004) states that the translator will deal with many translations problems, such as target text legibility, which is the errors that happen by using inappropriate words or vocabulary. This kind of difficulty is one of the lexical difficulties are frequently occur during the translation process. The difference may depend on the context and also the sense of idiomatic or literal.

On the other hand, there are three problems in translation related to the lexical category: polysemous meaning, differential/non-differential, and semantic field (Moentaha, 2006). The first is the polysemous meaning, which may result in difficulty for the translator in choosing the most proper words. Therefore, to cope with the difficulty, the translator should be critical in choosing a lexical category of a word during translation. The second is the differential and non-differential of a word. It means a word that might have a larger or narrower meaning in the target language. For example, the word 'rice' in Indonesian can be translated as 'padi,' 'beras,' and 'nasi.' It means that the word 'rice' has the narrower meaning when it is translated in Bahasa Indonesia since it is translated into the more specific words a s mention above. In other words, we can say that 'rice' is nondifferential since it has a larger meaning, meanwhile 'padi,' 'beras,' and 'nasi' is the differential since they have a narrower meaning than 'rice'. Some other words may have the same thing, such as 'house', which might be translated into the narrower counterparts 'rumah,' 'gedung,' 'graha.' The third is the semantic area of the context of the word. Related to the semantic area, translator should get the right perception toward the related context. In case the translator is unable to find the meaning of a word, it is possible for the translator to guess the meaning of the idiomatic expression by seeing through the context and replacing the idiomatic expression with the suitable word according to the given context. However, when the translator encounters lexical difficulty in this stage, the translator or student might accidentally put the equivalence from the other context. This kind of thing will create some problems of translation such as awkward translation or further the misinterpretation of the message.

\section{Grammatical Difficulties}

Some difficulties refer to grammatical issues. The first is the singular and plural forms of nouns. In English, we can easily find plural form indicators in most nouns, for example $-s$ in books, parents or -es in words like foxes, boxes, etc. In Indonesia, there is no suffix as plural or singular form indicator. However, the difference mentioned above may lead to the noun in plural form. As a result, the translator, in this case, the student will encounter grammatical difficulty. The error which is frequently found as the result of grammatical difficulty is:

a) ST: mother cooks dinner for her children.

TT: Ibu memasak makan malam untuk anaknya. 
b) ST: Anne mempunyai empat saudara laki-laki.

TT: Anne has for brother.

The second is the problem of aspect. Aspect is the grammatical category used to explain whether an event is still in progress, habitual, repeated, or have done. It is usually marked by prefixes, suffixes, and auxiliary verbs which attached to a verb. For example, the form writes, wrote, written, is writing. What makes them difficult is because those kinds of things do not exist in the Indonesian grammatical system. Instead of using prefixes and suffixes, Bahasa Indonesia employs the adverb of time as the indicator.

The last problem related to the grammatical structure is the difficulty in translating genus. The Genus indicator in Indonesia is different from the genus in English. English has more varied indicators, for example hero - heroine, waiter - waitress, aviator - aviatrix, and the other irregular form like jack ass - jenny ass, tom cat - tabby cat, billy goat - nanny goat. In the other hand, Bahasa Indonesia only have -wan and -wati, - $a$ and -i, pria wanita, jantan - betina. The fact that English has more varied genus indicators creates difficulty for Indonesian students since they might be unfamiliar with those involved words.

\section{Stylistic Difficulties}

Stylistic difficulties are the difficulties of translation that relate to any language styles that might be in the form of utterances, collocations, writing style, and figurative language. As a matter of style, the difficulties may relate to the utterance meaning, which might be different depending on the context and the intention. A phrase or an utterance may have the same form. However, it may have a different role in different contexts and intentions, whether it is figurative or literal, connotative or denotative.

These difficulties might occur when translators were translating metaphoric utterances, idiomatic expressions, simile, personification, alliteration, illocutionary verbs, illocutionary utterances, proper names, onomatopoeia, euphemism, and proverbs.

\section{Cultural Difficulties}

Cultural knowledge and difference are some of the biggest concerns in translation from the very beginning, especially in terms or expressions that are exclusively ground in one culture, which is almost impossible to translate (Douglas, 2003). Therefore, besides the cultural differences, the translator's background knowledge about the target language culture will also influence the translating process. It also happens in the process of idiomatic translation. Sometimes, some expressions are exclusively ground in one culture and do not exist in their culture. As proposed by Davies as cited in (Akbari, 2013), the cultural problem may result in recognition difficulty. It is obvious how we can recognize something that even does not exist in our culture. We know that the key to recognizing something is when we are accustomed to that thing. For example, students who use 
English as a means of communication and never study the culture will not recognize the culture in the form of language, such as idiomatic expression.

Despite those problems, the result of idiomatic translation should be properly translated into the target language and should be culturally accepted. It is because culture may have different agreements compared to the other culture. One of the examples is the expression loose-tongued which means unrestrained or irresponsible in a speech given to gossiping. In western culture, they use the tongue to express the manner of irresponsible speech. On the other hand, Indonesia, which belongs to east culture, uses mouth instead of tongue for the expression related to speech in its culture. Hence, the equivalence of loosetongued in Indonesia is besar mulut, not besar lidah (Hartono, 2009).

In addition, Nababan (2016) mentions that difficulties in translation can emerge because of the difference of source language and target language system, the complexity of stylistic, the difference of translator competence level, and the quality level of the source language.

\section{The Difference of SL and TL System}

Translation would not be a difficult task if every language in this world had same system. In fact, each language in this word has a different semantic, lexical, and morpheme system. For example, in a nominal sentence of Indonesian, the word of 'adalah' must not always exist in sentences. 'Adalah' must exist in a sentence when it is stating a definition. While in English, to be (is, am, are, was, and were) must exist in every nominal sentence. Another example, in English, "inconceivable" is written in one word but it derives from three morphemes: in, conceive, and able. When inconceivable is transferred into Indonesian, it will be written in three words and morphemes: 'tidak dapat dibayangkan'.

1. The Complexity of Stylistic

The complexity of stylistic is also one of the factors in emerging the difficulties in translation because it has a different style in expressing the message. The writing style of the text will affect the difficulty level of the translation. For example, literary texts such as poetry, prose, and drama are expressed differently from science texts. It means that the difficulty in translating literary text will be different from the translation of the science text.

2. The Difference Level of Competence

The competence level of the translator relates to the translators' background knowledge. The difficulties in the translation process may decrease if the translators have good competence and background knowledge. Therefore, before translating a text, translators must have background knowledge of the text to be translated. 
3. The Quality Level of the Source Language components

The translation process can also be caused by the poor level of the source language components text forms. For example, if the source language contains incorrect spelling, incorrect sentence structure, and functional. It will make the message from the source language difficult to comprehend and transfer to the target language.

\section{METHOD}

This research used a qualitative research type with a descriptive approach. The population consisted of 163 students of the fourth semester of the English Education Department. The researchers used purposive sampling as a technique to gain the sample. Based on the number of students in this semester, the researchers took a sample of $30 \%$ of 163 students, so there were 50 students. The sample of this research took 25 students of each two classes. Data and source of data of this research include translation result of English news report text entitled, "London is the Best Destination in the World in the 2019 Trip Advisor Travellers' Choice Awards" that have been translated into Indonesian by 50 students.

In analyzing the data, the researchers conducted four steps: 1) collecting students' translation results, the researchers took the data after the students finished translating the English News Report. 2) Identifying the difficulties, after collecting the translation result texts, the writer identified and classified the difficulties based on the types of translation difficulties based on Hartono's theory. 3) Analysing the difficulties, and. 4) Explaining and evaluating the difficulties, the writer explained the difficulties and then evaluating them.

\section{RESULTS AND DISCUSSION}

\section{Results}

The following tables express students' results in translating the English News Report. There are 5 sentences will be elaborated here.

\section{The students' translation and category of difficulties found in translating the first sentence}

The first sentence that should be translated was 'London is the Best Destination in the World in the 2019 TripAdvisor Travellers' Choice Awards.' The results of students' translation and the category of difficulties in translating the first sentence can be seen in table 1. below. 
Table 1.

Students' Translation Results in Translating the First Sentence

\begin{tabular}{|c|c|c|}
\hline No & Students Translation & $\begin{array}{l}\text { Category of } \\
\text { Difficulties }\end{array}$ \\
\hline 1 & $\begin{array}{l}\text { London sebagai destinasi terbaik di dunia dalam penghargaan } \\
\text { TripAdvisor tahun } 2019 \text { 'Penghargaan Pilihan' }\end{array}$ & Stylistic \\
\hline 2 & $\begin{array}{l}\text { London adalah destinasi penghargaan terbaik dunia di tahun } 2019 \\
\text { dalam Tripadvisor Travellers' Choice }\end{array}$ & Stylistic \\
\hline 3 & $\begin{array}{l}\text { London adalah pesona terbaik di dunia pelancong TripAdvisor di } \\
\text { tahun } 2019\end{array}$ & Lexical, stylistic \\
\hline 4 & $\begin{array}{l}\text { London adalah destinasi terbaik di dunia pada TripAdvisor } \\
\text { Pemilihan Penghargaan } 2019\end{array}$ & Lexical, stylistic \\
\hline 5 & $\begin{array}{l}\text { London adalah destinasi terbaik di dunia di pemilihan } \\
\text { penghargaan TripAdvisor tahun } 2019\end{array}$ & Lexical, stylistic \\
\hline 6 & $\begin{array}{l}\text { London adalah pesona terbaik di dunia TripAdvisor Travellers di } \\
2019\end{array}$ & Lexical \\
\hline 7 & $\begin{array}{l}\text { London adalah tujuan terbaik di dunia dalam penghargaan } \\
\text { penerbangan TripAdvisor } 2019\end{array}$ & Lexical, stylistic \\
\hline 8 & $\begin{array}{l}\text { London adalah tujuan yang terbaik di dunia di } 2019 \text { TripAdvisor } \\
\text { pilihan dunia }\end{array}$ & Lexical, stylistic \\
\hline 9 & $\begin{array}{l}\text { London adalah destinasi terbaik di dunia di TripAdvisor Travellers' } \\
2019 \text { pilihan penghargaan }\end{array}$ & Stylistic \\
\hline 10 & $\begin{array}{l}\text { London adalah tempat tujuan terbaik di dunia pada tahun } 2019 \text { di } \\
\text { ajang penghargaan TripAdvisor Travellers }\end{array}$ & Stylistic \\
\hline 11 & $\begin{array}{l}\text { London adalah tujuan perjalanan yang terbaik di dunia pada tahun } \\
\text { 2019, Penghargaan Tahunan Wisatawan TripAdvisor }\end{array}$ & Lexical, stylistic \\
\hline 12 & $\begin{array}{l}\text { London adalah tujuan yang terbaik di dunia di tahun } 2019 \text { untuk di } \\
\text { kunjungi Penghargaan Tahunan Wisatawan TripAdvisor }\end{array}$ & Lexical, stylistic \\
\hline 13 & $\begin{array}{l}\text { London adalah tujuan wisata terbaik di dunia } 2019 \text { TripAdvisor } \\
\text { Penghargaan Traveller's Choice Awards }\end{array}$ & Stylistic \\
\hline
\end{tabular}

The Table 1 showed us that in the sentence (the title of the article), most students had difficulties in lexical and stylistic aspects. From the table, it can be seen that there were five varieties of translation were categorized only in stylistic difficulties, and the rest of translation were categorized in both stylistic and lexical difficulties.

\section{The students' translation and category of difficulties found in translating the second sentence}

The second sentence that should be translated was 'London has been named the bestrated destination in the world in TripAdvisor's annual Travellers' Choice awards for destination.' The results of students' translation and the category of difficulties in translating the second sentence can be seen in table 2 . below. 
Table 2.

Students' Translation Result in Translating the Second Sentence

\begin{tabular}{|c|c|c|}
\hline No & Students Translation & $\begin{array}{l}\text { Category of } \\
\text { Difficulties }\end{array}$ \\
\hline 1 & $\begin{array}{l}\text { London telah diberinama tujuan terbaik di dunia di penghargaan } \\
\text { pilihan wisatawan tahunan TripAdvisor untuk tujuan tertentu. }\end{array}$ & Lexical, stylistic \\
\hline 2 & $\begin{array}{l}\text { London telah dijuluki sebagai destinasi terbaik di dunia dalam } \\
\text { acara tahunan TripAdvisor's Travellers' Choice Awards untuk } \\
\text { destinasi }\end{array}$ & Lexical \\
\hline 3 & $\begin{array}{l}\text { London telah dijuluki dengan destinasi terbaik di dunia dalam } \\
\text { acara tahunan TripAdvisor pemilihan penghargaan destinasi }\end{array}$ & Lexical, stylistic \\
\hline 4 & $\begin{array}{l}\text { London telah dinobatkan sebagai destinasi berperingkat terbaik di } \\
\text { dunia dalam penghargaan TripAdvisor Travellers' Choice Award } \\
\text { tahunan sebagai destinasi }\end{array}$ & Lexical, stylistic \\
\hline 5 & $\begin{array}{l}\text { London telah diberinama destinasi terbaik di dunia dalam tahunan } \\
\text { TripAdvisor Travellers' Choice Award untuk tempat tujuan }\end{array}$ & Lexical, stylistic \\
\hline 6 & $\begin{array}{l}\text { London telah dinobatkan sebagai destinasi terbaik di dunia } \\
\text { menurut TripAdvisor tahunan yang menunjuk untuk destinasi. }\end{array}$ & Stylistic \\
\hline 7 & $\begin{array}{l}\text { London dinobatkan sebagai destination terbaik dunia menurut } \\
\text { TripAdvisor tahunan untuk tujuan }\end{array}$ & Lexical \\
\hline 8 & $\begin{array}{l}\text { London telah dinamai sebagai tempat dengan peringkat terbaik di } \\
\text { dunia pada TripAdvisor Penghargaan Pilihan Wisatawan Destinasi } \\
\text { terbaik }\end{array}$ & Lexical \\
\hline 9 & $\begin{array}{l}\text { London sudah dinamakan sebagai tujuan wisata terbaik di dunia di } \\
\text { TripAdvisor's unnual travellers choice untuk tujuan wisata. }\end{array}$ & Lexical, stylistic \\
\hline 10 & $\begin{array}{l}\text { London telah dinamakan sebagai destinasi terbaik di dunia pada } \\
\text { TripAdvisor tahunan Travellers Choice Award untuk destinasi } \\
\text { wisata }\end{array}$ & Lexical \\
\hline 11 & $\begin{array}{l}\text { London merupakan nama destinasi di dunia dalam TripAdvisor } \\
\text { tahunan travel pilihan dunia untuk tempat }\end{array}$ & $\begin{array}{l}\text { Lexical, } \\
\text { grammatical, } \\
\text { stylistic }\end{array}$ \\
\hline 12 & $\begin{array}{l}\text { London memiliki nama perjalanan terbaik di dunia di TripAdvisor's } \\
\text { Travellers' tahunan suara penghargaan untuk destinasi }\end{array}$ & $\begin{array}{l}\text { Lexical, } \\
\text { grammatical, } \\
\text { stylistic }\end{array}$ \\
\hline 13 & $\begin{array}{l}\text { London dinobatkan sebagai destinasi terbaik di dunia di acara } \\
\text { TripAdvisor tahunan wisatawan penghargaan tahunan untuk } \\
\text { destinasi }\end{array}$ & Stylistic \\
\hline 14 & $\begin{array}{l}\text { London telah dinobatkan sebagai tempat wisata dengan nilai yang } \\
\text { tinggi di dunia dalam pemilihan TripAdvisor Travellers' Choice } \\
\text { Awards untuk kategori tempat-tempat-tempat wisata yang } \\
\text { diadakan setiap tahun. }\end{array}$ & Lexical, stylistic \\
\hline 15 & $\begin{array}{l}\text { London telah ternobat menjadi destinasi nilai terbaik di dunia } \\
\text { dalam TripAdvisor annual Travellers' pilihan penghargaan untuk } \\
\text { destinasi }\end{array}$ & $\begin{array}{l}\text { Lexical, } \\
\text { grammatical, } \\
\text { stylistic }\end{array}$ \\
\hline 16 & $\begin{array}{l}\text { London telah menjadi destinasi terbaik di dunia oleh TripAdvisor's } \\
\text { annual Travellelrs' choice awards sebagai tempat wisata }\end{array}$ & $\begin{array}{l}\text { Lexical, } \\
\text { grammatical, } \\
\text { stylistic }\end{array}$ \\
\hline
\end{tabular}




\begin{tabular}{lll}
\hline 17 & $\begin{array}{l}\text { London nama wisata yang paling terbaik di dunia TripAdvisor's } \\
\text { tahunan Travellers' choice awards untuk tujuan }\end{array}$ & $\begin{array}{l}\text { Lexical, } \\
\text { grammatical, } \\
\text { stylistic }\end{array}$ \\
\hline 18 & $\begin{array}{l}\text { London telah dinamakan tempat destinasi terbaik di seluruh dunia } \\
\text { dalam penghargaan TripAdvisor Travellers' tahunan penghargaan } \\
\text { kategori destinasi }\end{array}$ & Lexical, stylistic \\
\hline 19 & $\begin{array}{l}\text { London telah dijuluki sebagai destinasi tujuan terbaik di seluruh } \\
\text { dunia dalam ajang penghargaan TripAdvisor Travellers' tahunan } \\
\text { untuk destinasi }\end{array}$ & Lexical, stylistic \\
\hline
\end{tabular}

Table 2 reported students generally had difficulties in lexical, stylistic, and grammatical aspects. From the table, it can be seen that there were four varieties of translation that were categorized only in lexical difficulties, two varieties of translation were categorized only in stylistic difficulties, eight varieties of translation were categorized in both lexical and stylistic difficulties, and the rest varieties of translation were categorized in lexical, stylistic and grammatical difficulties.

\section{The students' translation and category of difficulties found in translating the third sentence}

The third sentence that should be translated was 'London has been named the bestrated destination in the world in TripAdvisor's annual Travellers' Choice awards for destination.' The results of students' translation and the category of difficulties in translating the third sentence can be seen in Table 3. below.

Table 3.

Students' Translation Result in Translating the Third Sentence

\begin{tabular}{|c|c|c|}
\hline No & Students Translation & $\begin{array}{l}\text { Category of } \\
\text { Difficulties }\end{array}$ \\
\hline 1 & $\begin{array}{l}\text { Pemenang ditentukan menggunakan algoritme dengan } \\
\text { menganalisa sejuta tinjauan dan rangking untuk hotel-hotel, rumah } \\
\text { makan-rumah makan dan pertunjukkan-pertunjukkan yang } \\
\text { dihitung dalam satu tahun dari pelancong lintas dunia TripAdvisor }\end{array}$ & $\begin{array}{l}\text { Grammatical, } \\
\text { lexical, stylistic }\end{array}$ \\
\hline 2 & $\begin{array}{l}\text { Para pemenang ditentukan menggunakan sebuah algoritme yang } \\
\text { menganalisis jutaan resensi dari penilaian hotel, restoran, dan } \\
\text { kumpulan acara dalam satu tahun dari pelancong. }\end{array}$ & Lexical, stylistic \\
\hline 3 & $\begin{array}{l}\text { Pemenangnya telah ditentukan menggunakan sebuah algoritma } \\
\text { yang menganalisis jutaan tinjauan dan peringkat untuk hotel-hotel, } \\
\text { restaurant-restaurant, dan daya tarik di satu tahun penghargaan } \\
\text { TripAdvisor Travellers }\end{array}$ & $\begin{array}{l}\text { Grammatical, } \\
\text { stylistic }\end{array}$ \\
\hline 4 & $\begin{array}{l}\text { Pemenang telah menentukan penggunaan sebuah algoritma yang } \\
\text { meneliti jutaan tinjauan dari rating untuk hotel, restauran, dan } \\
\text { kumpulan atraksi dalam satu tahun dari TripAdvisor travellers } \\
\text { meliputi seluruh dunia }\end{array}$ & $\begin{array}{l}\text { Grammatical, } \\
\text { stylistic }\end{array}$ \\
\hline 5 & $\begin{array}{l}\text { Pemenang ditentukan menggunakan algoritme penelitian juta dari } \\
\text { tinjauan dan penilaian dari hotel-hotel, restorant, dan kumpulan } \\
\text { daya tarik dalam satu tahun dalam TripAdvisor travellers mendunia }\end{array}$ & $\begin{array}{l}\text { Grammatical, } \\
\text { stylistic }\end{array}$ \\
\hline
\end{tabular}


$6 \quad$ Pemenang yang bertekad menggunakan sebuah algoritme jutaan analisis pemeriksaan dan penilaian untuk hotel, rumah makan, dan menarik dalam pengambilan sebuah satu-satunya tahun dari TripAdvisor perjalanan mendunia
Grammatical, stylistic

In Table 3 above, students mostly had difficulties in grammatical, lexical and stylistic apsects. From the table, it can be seen that there were 3 varieties of translation were categorized, 1 translation was categorized in grammatical, lexical and stylistic difficulties, 1 translation were categorized in both lexical and stylistic difficulties, and the rest varieties of translation were categorized in both grammatical and stylistic difficulties.

\section{The students' translation and category of difficulties found in translating the fourth sentence}

The fourth sentence that was translated was 'Paris takes second spot this year, with Rome rolling in at third place and Crete in fourth. However, New York, a long-time favorite with travelers worldwide, slips out of the top 10 completely' The results of students' translation and the category of difficulties in translating the fourth sentence can be seen in table 4. Below.

Table 4.

Students' Translation Result in Translating the Fourth Sentence

\begin{tabular}{|c|c|c|}
\hline No & Students Translation & $\begin{array}{l}\text { Category of } \\
\text { Difficulties }\end{array}$ \\
\hline 1 & $\begin{array}{l}\text { Paris menduduki tempat kedua tahun ini, dan Roma berdiri di } \\
\text { tempat ketiga dan Crete di posisi keempat. Namun, New York } \\
\text { favorit terlama dengan wisatawan di seluruh dunia, keluar dari } 10 \\
\text { besar sepenuhnya. }\end{array}$ & Lexical, stylistic \\
\hline 2 & $\begin{array}{l}\text { Paris menempati posisi kedua tahun ini, dengan Roma di posisi } \\
\text { ketiga dan Crete di posisi empat. Namun, New York, yang telah } \\
\text { lama menjadi favorit di seluruh dunia, lolos di } 10 \text { besar. }\end{array}$ & Lexical \\
\hline 3 & $\begin{array}{l}\text { Paris mengambil tempat kedua tahun ini, dengan Roma bergulir di } \\
\text { tempat ketiga dan Crete di tempat keempat. Bagaimanapun, New } \\
\text { York, kesukaan pelancong di seluruh dunia sejak lama, tergelincir } \\
\text { keluar dari sepuluh besar sepenuhnya. }\end{array}$ & Stylistic \\
\hline 4 & $\begin{array}{l}\text { Paris menempati urutan kedua tahun ini, dengan Roma di urutan } \\
\text { ketiga dan Crete di urutan keempat. Bagaimanapun, New York, } \\
\text { kesukaan sejak lama dari pelancong lintas dunia. }\end{array}$ & Stylistic \\
\hline 5 & $\begin{array}{l}\text { Paris dinobatkan sebagai tempat tujuan terbaik kedua di tahun ini, } \\
\text { bergantian dengan Roma sebagai nama ketiga dan Crete di nomor } \\
\text { empat. Namun, New York, adalah tempat tujuan terlama yang } \\
\text { menjadi favorit oleh para pelancong di seluruh dunia, lolos dari } 10 \\
\text { besar dengan sempurna. }\end{array}$ & Lexical, stylistic \\
\hline 6 & $\begin{array}{l}\text { Paris mengambil tempat kedua tahun ini, dengan Roma bergilir di } \\
\text { tempat ketiga dan Crete di tempat keempat. Namun, New York, } \\
\text { favorit lama dengan traveller di seluruh dunia, lolos dari } 10 \text { besar. }\end{array}$ & Stylistic \\
\hline
\end{tabular}




\begin{tabular}{|c|c|c|}
\hline 7 & $\begin{array}{l}\text { Paris menduduki posisi kedua tahun ini, dengan Roma bergulir di } \\
\text { posisi ketiga dan Crete di posisi keempat. Meskipun, New York, } \\
\text { merupakan favorit lama dengan pelancong di seluruh dunia, } \\
\text { menyelinap keluar dari top } 10 \text {. }\end{array}$ & Lexical, stylistic \\
\hline 8 & $\begin{array}{l}\text { Paris mendapatkan posisi kedua tahun ini, dengan Roma yang } \\
\text { mengikutinya di posisi ketiga dan Kreta di posisi keempat. Bahkan, } \\
\text { New York, yang untuk waktu lama menjadi favorit wisatawan } \\
\text { dunia, terlempar dari } 10 \text { teratas. }\end{array}$ & Stylistic \\
\hline 9 & $\begin{array}{l}\text { Paris menjadi spot kedua tahun ini, sedangkan Roma menjadi } \\
\text { tempat ketiga dan Crete menjadi tempat keempat. Bagaimanapun, } \\
\text { New York, jangka waktu terlama untuk tempat wisata di seluruh } \\
\text { dunia, menyelinap keluar dari top } 10 .\end{array}$ & Lexical, stylistic \\
\hline 10 & $\begin{array}{l}\text { Paris menjadi spot kedua tahun ini, sedangkan Roma menjadi spot } \\
\text { ketiga dan Crete menjadi spot keempat. Bagaimanapun, New York, } \\
\text { merupakan jangka waktu terlama untuk tempat wisata di seluruh } \\
\text { dunia, keluar dari top } 10 \text {. }\end{array}$ & Stylistic \\
\hline 11 & $\begin{array}{l}\text { Paris menjadi spot kedua tahun ini, sedangkan Roma menjadi } \\
\text { tempat ketiga dan Crete menjadi tempat keempat. Bagaimanapun, } \\
\text { New York, menjadi tempat wisatawan dalam jangka waktu terlama } \\
\text { di seluruh dunia, keluar dari top } 10 \text {. }\end{array}$ & Stylistic \\
\hline 12 & $\begin{array}{l}\text { Paris menjadi spot kedua tahun ini, sedangkan Roma menjadi } \\
\text { tempat ketiga dan Crete berada di tempat keempat. } \\
\text { Bagaimanapun, New York, pada jangka waktu terlama untuk } \\
\text { tempat wisata di dunia, lolos dari top } 10 .\end{array}$ & Stylistic \\
\hline 13 & $\begin{array}{l}\text { Paris mengambil spot kedua di tahun ini, dengan kota sebagai } \\
\text { tempat ketiga dan Crete di bagian empat. Bagaimanapun, New } \\
\text { York, sejak lama dahulu menjadi yang favorit oleh travellers } \\
\text { seluruh dunia, keluar dari top } 10 .\end{array}$ & Stylistic \\
\hline 14 & $\begin{array}{l}\text { Paris memegang tempat kedua tahun ini, dengan Roma } \\
\text { bergelinding ke tempat ketiga dan Crete keempat. Bagaimanapun, } \\
\text { New York, favorit terlama dengan travellers mendunia, merosot ke } \\
\text { puncak } 10 \text { seutuhnya. }\end{array}$ & Stylistic \\
\hline 15 & $\begin{array}{l}\text { Paris menempati posisi kedua tahun ini, dengan Roma masuk di } \\
\text { posisi ketiga dan Kreta di depan. Namun, New York, yang sudah } \\
\text { lama menjadi favorit para wisatawan di seluruh dunia, lolos dari } \\
\text { sepuluh besar. }\end{array}$ & Lexical, stylistic \\
\hline 16 & $\begin{array}{l}\text { Paris menempati posisi kedua tahun ini, dengan Roma turun di } \\
\text { posisi ketiga dan Crete keempat. Bagaimanapun, New York, yang } \\
\text { lama menjadi favorit di travellers worldwide, keluar dari } 10 \text { besar } \\
\text { teratas sepenuhnya. }\end{array}$ & Stylistic \\
\hline 17 & $\begin{array}{l}\text { Paris berada di posisi kedua tahun ini, dengan Roma di tempat } \\
\text { ketiga dan Yunani di tempat keempat. Bagaimanapun, New York, } \\
\text { tempat terfavorit sepanjang masa bagi pengunjung di seluruh } \\
\text { dunia, New York merangsek masuk } 10 \text { besar teratas. }\end{array}$ & Stylistic \\
\hline 18 & $\begin{array}{l}\text { Paris mengambil kedua bagian dunia ini, dengan Roma di tempat } \\
\text { ketiga dan Crete keempat. Namun, New York, sebuah waktu lama } \\
\text { yang disenangi dengan berjalan mendunia, di luar } 10 \text { puncak } \\
\text { mencapai. }\end{array}$ & Stylistic \\
\hline
\end{tabular}


19 Paris mendapatkan posisi kedua tahun ini, bersama dengan Roma Stylistic yang bertukar pada posisi ketiga dan Crete di posisi keempat. Bagaimanapun, New York sudah sangat lama menjadi tempat favorit para traveller mendunia, sebagian dari posisi atas 10 mutlak.

Table 4 expressed that generally, students get difficulties translating the fourth sentence's English news report happen to stylistic difficulties. There are only one of them finds difficulties lexically.

\section{The students' translation and category of difficulties found in translating the fifth sentence}

The last sentence that was translated was "London came second in 2018, and TripAdvisor says that its move into the top spot might be connected to the wedding of the Duke and Duchess of Sussex.' The results of students' translation and the category of difficulties in translating that sentence are presented in table 5 below.

Table 5.

Students' Translation Result in Translating the Fifth Sentence

\begin{tabular}{|c|c|c|}
\hline No & Students Translation & $\begin{array}{l}\text { Category of } \\
\text { Difficulties }\end{array}$ \\
\hline 1 & $\begin{array}{l}\text { London datang pada tempat kedua di tahun } 2018 \text { dan } \\
\text { TripAdvisor mengatakan bahwa itu bisa berpindah ke dalam } \\
\text { tempat teratas mungkin berhubungan dengan pernikahan Duke } \\
\text { dan Duches of Sussex. }\end{array}$ & $\begin{array}{l}\text { Lexical, stylistic, } \\
\text { cultural }\end{array}$ \\
\hline 2 & $\begin{array}{l}\text { London menempati urutan kedua pada tahun } 2018 \text { dan } \\
\text { TripAdvisor mengatakan bahwa London masuk ke dalam sepuluh } \\
\text { tingkatan atas terkait dengan pernikahan dari Harry dan } \\
\text { Meghan. }\end{array}$ & Stylistic \\
\hline 3 & $\begin{array}{l}\text { London yang berada di urutan kedua pada tahun } 2018 \text { dan } \\
\text { TripAdvisor mengatakan bahwa perpindahannya ke posisi } \\
\text { teratas mungkin terkait dengan pernikahan Duke dan Duches of } \\
\text { Sussex. }\end{array}$ & $\begin{array}{l}\text { Stylistic, } \\
\text { cultural }\end{array}$ \\
\hline 4 & $\begin{array}{l}\text { London berada di urutan kedua pada tahun 2018, TripAdvisor } \\
\text { mengatakan bahwa perpindahan London ke posisi dua } \\
\text { disebabkan karna pernikahan Duke dan Duchess of Sussex. }\end{array}$ & $\begin{array}{l}\text { Stylistic, } \\
\text { cultural }\end{array}$ \\
\hline 5 & $\begin{array}{l}\text { London berada di urutan kedua pada tahun } 2018 \text { dan } \\
\text { TripAdvisor mengatakan bahwa perpindahannya ke posisi } \\
\text { teratas yang berkaitan dengan pernikahan Duke dan Duchess of } \\
\text { Sussex. }\end{array}$ & $\begin{array}{l}\text { Stylistic, } \\
\text { cultural }\end{array}$ \\
\hline 6 & $\begin{array}{l}\text { London menjadi posisi kedua pada tahun } 2018 \text { dan TripAdvisor } \\
\text { menyatakan perpindahan posisi teratas berhubungan dengan } \\
\text { pernikahan pangeran dan putri Sussex. }\end{array}$ & $\begin{array}{l}\text { Lexical, stylistic, } \\
\text { cultural }\end{array}$ \\
\hline 7 & $\begin{array}{l}\text { London menjadi urutan kedua di } 2018 \text { dan TripAdvisor } \\
\text { mengatakan bahwa pindah kebagian atas kemungkinan } \\
\text { berhubungan dengan pernikahan Duke dan Duchess of Sussex. }\end{array}$ & $\begin{array}{l}\text { Lexical, stylistic, } \\
\text { cultural }\end{array}$ \\
\hline
\end{tabular}




\begin{tabular}{|c|c|c|}
\hline 8 & $\begin{array}{l}\text { London menjadi urutan kedua di } 2018 \text { dan TripAdvisor } \\
\text { mengatakan bahwa bergeser kebagian atas kemungkinan } \\
\text { berhubungan dengan pernikahan Duke dan Duchess of Sussex. }\end{array}$ & $\begin{array}{l}\text { Lexical, stylistic, } \\
\text { cultural }\end{array}$ \\
\hline 9 & $\begin{array}{l}\text { London menjadi yang kedua di tahun } 2018 \text { dan TripAdvisor } \\
\text { mengatakan bahwa itu beralih ke dalam spot top yang bisa } \\
\text { dihubungkan ke pernikahan Adipati dan wanita bangsawan dari } \\
\text { Sussex. }\end{array}$ & $\begin{array}{l}\text { Stylistic, } \\
\text { cultural }\end{array}$ \\
\hline 10 & $\begin{array}{l}\text { London datang sebagai kedua di tahun } 2018 \text { dan TripAdvisor } \\
\text { berkata bahwa London berpindah menjadi top spot yang } \\
\text { menghubungkan ke pernikahan dari pejabat dan wanita } \\
\text { bangsawan. }\end{array}$ & $\begin{array}{l}\text { Stylistic, } \\
\text { cultural }\end{array}$ \\
\hline 11 & $\begin{array}{l}\text { London datang tempat kedua dalam tahun } 2018 \text { dan TripAdvisor } \\
\text { mengatakan bahwa itu pindah ke dalam tempat terbaik mungkin } \\
\text { berhubungan dengan pernikahan dari Duke dan Duchess dari } \\
\text { Sussex. }\end{array}$ & $\begin{array}{l}\text { Stylistic, } \\
\text { cultural }\end{array}$ \\
\hline 12 & $\begin{array}{l}\text { London datang kedua di } 2018 \text { dan TripAdvisor mengatakan } \\
\text { bahwa itu adalah pemberhentian titik terkuat yang disambungkan } \\
\text { ke pernikahan dari Duke dan Duchess dari Sussex. }\end{array}$ & $\begin{array}{l}\text { Lexical, stylistic, } \\
\text { cultural }\end{array}$ \\
\hline 13 & $\begin{array}{l}\text { London menempati urutan kedua pada tahun } 2018 \text { dan } \\
\text { TripAdvisor mengatakan bahwa kepindahannya ke posisi teratas } \\
\text { mungkin terkait dengan pernikahan Adipati dan Adipati wanita } \\
\text { Sussex. }\end{array}$ & Cultural \\
\hline 14 & $\begin{array}{l}\text { London datang kedua di } 2018 \text { dan TripAdvisor mengatakan } \\
\text { bahwa London bergerak ke tempat teratas mungkin } \\
\text { berhubungan dengan pernikahan bangsawan laki-laki dan } \\
\text { bangsawan perempuan. }\end{array}$ & $\begin{array}{l}\text { Stylistic, } \\
\text { cultural }\end{array}$ \\
\hline 15 & $\begin{array}{l}\text { London menempati posisi kedua pada tahun } 2018 \text { dan } \\
\text { TripAdvisor mengatakan perpindahan London ke dalam posisi } \\
\text { teratas yang mungkin menjadi penghubung atas pernikahan sang } \\
\text { Duke dan Duchess of Sussex. }\end{array}$ & $\begin{array}{l}\text { Stylistic, } \\
\text { cultural }\end{array}$ \\
\hline 16 & $\begin{array}{l}\text { London kembali hadir yang kedua kalinya di tahun } 2018 \text { dan } \\
\text { TripAdvisor mengatakan bahwa London menjadi spot teratas } \\
\text { dikarenakan berhubungan dengan pernikahan the Duke dan } \\
\text { Duchess of Sussex. }\end{array}$ & $\begin{array}{l}\text { Lexical, stylistic, } \\
\text { cultural }\end{array}$ \\
\hline 17 & $\begin{array}{l}\text { London kembali hadir yang kedua kalinya di tahun } 2018 \text { dan } \\
\text { penasihat trip mengatakan bahwa London menjadi spot teratas } \\
\text { yang mungkin terhubung ke pernikahan Duke dan Duchess } \\
\text { Sussex. }\end{array}$ & $\begin{array}{l}\text { Lexical, stylistic, } \\
\text { cultural }\end{array}$ \\
\hline 18 & $\begin{array}{l}\text { London datang dengan urutan kedua di tahun } 2018 \text { dan } \\
\text { TripAdvisor berkata bahwa London beralih menjadi tempat/titik } \\
\text { terbaik mungkin karena dihubung-hubungkan dengan } \\
\text { pernikahan dari Duke dan Duchess dari Sussex (Harry dan } \\
\text { Meghan). }\end{array}$ & Stylistic \\
\hline 19 & $\begin{array}{l}\text { London datang kedua di } 2018 \text { dan TripAdvisor itu berkata } \\
\text { memindahkan ke dalam melihat puncak tengah malam menjadi } \\
\text { berhubungan ke perkawinan the Duke dan Duchess of Sussex. }\end{array}$ & $\begin{array}{l}\text { Lexical, stylistic, } \\
\text { cultural }\end{array}$ \\
\hline
\end{tabular}


In Table 5, students generally had difficulties in lexical, stylistic, and also cultural aspects. From the table, it can be seen that there were two varieties of translation were categorized only in stylistic difficulties. One translation was categorized only in both lexical and cultural difficulties, one translation was categorized only in cultural difficulties, eight varieties of translation were categorized in lexical, stylistic, and cultural difficulties, and nine varieties of translation were categorized in both stylistic and cultural difficulties.

\section{Discussion}

The result of the data presented above indicates that all types of translation difficulties based on Hartono's point of view were found in this research. These are lexical difficulties, stylistic difficulties, grammatical difficulties, and cultural difficulties.

\section{Lexical difficulties}

Generally, lexical difficulties happened because the students were unable to identify the proper meaning of the texts. They could not determine equivalence word correctly in the target language; for example, in translating 'Best Destination,' they translated it into 'Pesona terbaik', which is less appropriate and sounded unnatural in target language, because it should be translated into 'Destinasi terbaik/tempat wisata terbaik', so that the translation can be accepted. Another mistake occurred when students were translating 'million of reviews' into 'miliaran ulasan', which is incorrectly transferred because the word 'million' should be translated into 'jutaan'. In translating 'Entrepenurship', students made mistakes and translated it into 'kewiraswastaan', which the translation was transferred inaccurately, it should be translated into 'kewirausahaan'. These are the problems accordance with Davies (2004) state that the translator will deal many problems of translations, such as target text legibility which is the errors happen by using inappropriate word or vocabulary which appear when the translator is unable to understand, misunderstand, or barely do not know the meaning of a word or an expression.

According to Hartono (2009), there were three problems in lexical difficulties, including differential and non-differential of a word that students could not recognize in translating these texts. It could be seen when students were translating 'students' into 'murid', while it should be translated into 'mahasiswa'. It is because the word 'student' had a larger meaning in the target language.

\section{Stylistic Difficulties}

Stylistic difficulties occurred because English news reports have its own language style different from other kinds of text. According to Choliludin (2009), the ways a translator translates English text, including news reports, are in accordance with the steps mentioned before especially for news articles should be translated idiomatically. As Larson stated that try to translate to the idiomatic point. Nonetheless, in arranging 
phrases or sentences, students mostly translated word for word without determining the target language system. For example, students translated 'London has been named' into 'London telah diberi nama' which is the translation could not be said wrong because of literal meaning it was right, however, idiomatically it should be translated into 'London telah dinobatkan' so as the translation sounded natural and acceptable in target language. Another mistakes found when students were translating the phrase 'a long-time favourite with travellers worldwide' into 'sebuah waktu panjang favorit dengan para travellers lintas dunia' which translation was translated word for word without changing target language system. It should be translated into 'sejak lama menjadi favorit bagi wisatawan dunia' which sounded more natural and easy to understand.

In translating ' $5^{\text {th }}$ UNESCO-APEID Meeting on Entrepreneurship Education' which it is the name of the event, means students can translated it into target language or allow it originally. However, students made mistakes when translating it such as 'UNESCO-APEID kelima pertemuan Pendidikan Kewirausahaan' which the translation was arranged inaccurately, it could be translated into 'rapat Unesco-APEID kelima tentang Pendidikan Kewirausahaan'

In addition, illocutionary verbs are also a problem in translating English news report as stated by Hartono (2009), illocutionary verbs are used in direct speech. In this case, students translated 'said in his speech' into 'kata dalam pidatonya' which the translation sounded stiff, since it should be translated into 'ujarnya dalam sambutan' so as the translation acceptable in target language.

\section{Grammatical Difficulties}

Grammatical difficulties generally were found in translating singular and plural forms of nouns used in both languages. The grammatical difficulties might occur because of some grammatical issues in English and Indonesian. In English, the plural form is written by adding s/es after countable noun, while in Indonesia, it is written by adding 'para' before the noun itself or by repeating the words. For example, students most translated 'the winners' into only 'pemenang' without determining plural form and wrote in still singular form. It is accordance with Moentaha (cited in Hartono, 2009), there were three problems in grammatical aspects on of them is plural/singular form of nouns.

Another difficulty also found is in form of active and passive voices. For example, in case of translating verbs, the word that should be translated as passive voice was translated into active form, and vice versa. In translating 'London has been named', students translated it into 'London memiliki nama' which the translation was translated word for word and in active sentence. It should be translated into 'London telah dinobatkan' so as acceptable in target language. Another mistakes found in translating 'organized by', students translated it into 'mengatur dengan' which the translation was incorrectly transferred because unappropriate word and in active sentence. 


\section{Cultural Difficulties}

Based on the data, cultural difficulties also occurred. Since both English and Indonesian languages are different from cultural background. In translating these texts, students could not recognise cultural aspects which had to be transferred. For example, students translated 'Duke and Duchess of Sussex' into 'bangsawan laki-laki dan bangsawan perempuan' which the translation was incorrectly transfered, and sounded awkwardly because they could not suit proper terminology that acceptable in target language. It should be translated into 'pangeran dan putri dari Sussex' or it could be translated into 'Harry and Meghan' which is accordance with the context.

\section{CONCLUSION}

The researchers conclude that there were four types of difficulties encountered by the fourth semester of English Education Department Students in translating the text of English News Report entitled, 'London is the Best Destination in the World in the 2019 Trip Advisor's Traveller' Choice Awards. The difficulties are lexical difficulties due to lack of vocabulary mastery, stylistic difficulties refer to students' background knowledge about language style used in news (article) both of the languages, grammatical difficulties relate to active and passive voice usage, cultural difficulties refers to Lack of background knowledge about cultural aspects both of the languages.

\section{REFERENCES}

Akbari, M. (2013). Strategies for Translating Idioms. Tehran: Islamic Azad University.

Choliludin. (2009). The Techniques of Making Idiomatic Translation. Jakarta: Kesaint Blanc.

Davies, M. G. (2004). Multiple Voices in the Translation Classroom: Activities, Tasks and Projects. Amsterdam: John Benjamins Publishing.

Dony, P. M. (2017). The Correlation between Translation Ability and Reading Habit Toward Writing Ability (A Correlation Study to the Twelfth Grade Students MAN 2 Surakarta in the Academic Year 2015/2016) (Thesis). IAIN Surakarta.

Douglas, R. (2003). Becoming A Translator: An Introduction to the Theory and Practice of Translation. London: Routledge.

Hariyanto, S., \& Suryawinata, Z. (2003). Translation: Bahasa Teori Penuntun Praktis Menerjemahkan. Yogyakarta: Penerbit Kanisius. Yogyakarta: Kanisius.

Hartono, R. (2009). Teori Penerjemahan (A Handbook for Translator). Semarang: Cipta Prima Nusantara.

Harvey, M. (2003). A Beginner's Course in Legal Translation: The Case of Culturebound.

Larson, M. (1998). Meaning-Based Translation (A Guide to Cross-Language Equivalence). Lanhan: University Press of America.

Moentaha, S. (2006). Bahasa dan Terjemahan. Jakarta: Kesaint Blanc.

Nababan, M. R. (2016). Teori Menerjemahkan Bahasa Inggris. Yogyakarta: Pustaka Pelajar.

Nida, E. A., \& Taber, C. R. (1974). The Theory and Practice of Translation. Leiden: E. J. Brill. 
PANYONARA: Journal of English Education Vol. 3, No. 2, September 2021

Ordudari, M. (2007). Translation Procedures, Strategies and Method. Translation Journal, 11(3).

Yazida, A. R. (2017). An Analysis of Errors Made by Ten Graders in Translating Descriptive Text at MAN 3 Amuntai (Thesis). UIN Antasari, Banjarmasin. 